сфере уточнения прав залогодержателя на участие в управлении, что будет способствовать единообразию судебной практики.

1. Гражданский кодекс РФ (часть первая). [Электронный ресурс]. Доступ из справ.-правовой системы «КонсультантПлюс».

2. Федеральный закон от 8 февраля 1998 г. № 14-Ф3 «Об обществах с ограниченной ответственностью». [Электронный ресурс]. Доступ из справ.-правовой системы «КонсультантПлюс».

3. Федеральный закон от 26 декабря 1995 г. № 208-Ф3 «Об акционерных обществах». [Электронный pecypc]. Доступ из справ.-правовой системы «КонсультантПлюс».

4. Корпоративное право: учебник / под. ред. И.С. Шиткиной. М.: Статут, 2019. С. 541.

5. Глушков Н. Залог корпоративных прав: пределы осуществления залогодержателем права на управление. [Электронный https://zakon.ru/blog/2019/04/29/zalog_korporativnyh_prav_predely_osuschestvleniya_zalogoderzhatelem_pra va_na_upravlenie

6. Определение Верховного суда РФ от 1 августа 2017 г. по делу № A73-18000/2015. [Электронный pecypc]. Доступ из справ.-правовой системы «КонсультантПлюс».

7. Постановление Арбитражного суда Уральского округа от 8 августа 2017 г. № Ф09-3590/17 по делу № А71-725/2016. [Электронный ресурс]. Доступ из справ.-правовой системы «КонсультантПлюс».

8. Постановление Арбитражного суда Северо-Западного округа от 5 апреля 2017 г. № Ф07-1700/2017 по делу № A56-22247/2016. [Электронный ресурс]. Доступ из справ.-правовой системы «КонсультантПлюс».

9. Постановление Арбитражного суда Московского округа от 21 февраля 2017 г. № $\Phi 05-60 / 2017$ по делу № A 40-220474/15. [Электронный ресурс]. Доступ из справ.-правовой системы «КонсультантПлюс».

10. Определение Верховного суда РФ от 30 мая 2017 г. № 309-ЭС17-5399 по делу № А07-21705/2015. [Электронный ресурс]. Доступ из справ.-правовой системы «КонсультантПлюс».

11. Постановление Девятнадцатого арбитражного апелляционного суда от 31 марта 2017 г. по делу № A365304/2016. [Электронный ресурс]. Доступ из справ.-правовой системы «КонсультантПлюс».

12. Постановление Арбитражного суда Уральского округа от 23 января 2017 г. № Ф09-12225/16 по делу № А 07-21705/2015. [Электронный ресурс]. Доступ из справ.-правовой системы «КонсультантПлюс».

13. Постановление Арбитражного суда Дальневосточного округа от 10 июня 2016 г. № Ф03-2348/2016 по делу № А73-17951/2015. [Электронный ресурс]. Доступ из справ.-правовой системы «КонсультантПлюс».

\title{
Стрыгина C.B.
}

Роль общеправовых принципов в правоприменительной деятельности

Саратовский национальный исследовательский государственный университет им. Н.Г.Чернышевского (Россия, Саратов)

doi: $10.18411 / 1 j-07-2019-45$

idsp: ljournal-07-2019-45

\section{Аннотация}

В статье обозначена роль общеправовых принципов права в правоприменительной практике. Это дает определенную свободу в принятии решения на основе позитивного и герменевтического метода, что позволяет обеспечить своевременное, правильное применение права и достигнуть конституционного равноправия.

Ключевые слова: принципы права, правоприменение, герменевтика, правовая определенность, позитивизм, судебное усмотрение.

\section{Abstract}

The article describes the role of General legal principles of law in law enforcement practice. This gives a certain freedom of decision-making on the basis of a positive and hermeneutic method, which makes it possible to ensure the timely, correct application of the law and achieve constitutional equality.

Keywords: principles of law, law enforcement, hermeneutics, legal certainty, positivism, judicial discretion.

В романо-германской правовой семье большую роль играют принципы права, которые лежат в основе как правотворчества, так и правоприменения. При этом в 
правоприменении им отводится особое место, поскольку от реализации зависит уважение к праву, отношение к нему как к механизму обеспечения свободы, равенства, гуманизма и справедливости.

Обращение к принципам права позволяет определить правовые ценности, поскольку назначение судебного решения заключается в том, чтобы в ходе разрешения конкретного дела выявить таковые, которые, возможно, и не зафиксированы в писаном праве, и положить их в основу решения.

Так, в основе каждого решения Конституционного суда лежит тот или иной общеправовой принцип права, это дает возможность определять вектор последующего изменения законодательства в стране, что способствует соблюдению прав человека и гражданина. Решения Конституционного Суда на основе конституционных принципов позволяют в дальнейшем судебным органам определять содержание и правовые последствия в контексте конкретного дела.

В случае возникновения противоречий относительно того, какая норма должна быть применена, решение будет зависеть от принципа, заложенного в основу конституционных норм. К примеру, в случае рассмотрения спора с участием социально незащищенных категорий населения (инвалидов, детей-сирот, многодетных семей и прочее), правоприменение исходит из конституционности социального государства, о котором говорится в ст. 7 Конституции РФ. В его основе должны быть заложены морально - этические принципы права, которые составляют нравственную основу социального государства: справедливость, равенство, достоинство. Организационные принципы права, которые выделял М.И. Байтин [1, С.150], (например законность, федерализм, сочетание убеждения и принуждения) при этом будут способствовать реальному обеспечению разрешения возникшей проблемы в правоотношении.

Принципы дают судье определенную сферу свободы, поскольку не диктуют конкретного решения, а предоставляют аргументы для принятия решения. Нормы права и принципы права выступают аргументами в обосновании решений, однако играют разную роль в логике аргументации. Использование судами принципов делает право более гибким и позволяет судам выносить решения в зависимости от обстоятельств конкретного дела.

Таким образом, принципы обеспечивают материальную комплектность правовой системы, для которой важнем учет судьей не только буквы, но и духа закона. Поэтому следует рассматривать процесс правоприменения, как с точки зрения позитивистского подхода, так и с точки зрения герменевтики. И если позитивизм требует установить, что хотел сказать в тексте законодатель, герменевтический метод, по мнению немецкого правоведа А. Кауфмана, дает понимание «действительного» права, поскольку в его основе заложено понятие свободы как естественного состояния человека [2, С.104]. Правильное понимание права судье нельзя извлечь только из нормы права, без учета его духа, который содержится в принципах права.

Как писал русский философ - правовед Иван Александрович Ильин: «То, что «сейчас» и «здесь» - право, то «завтра» и «здесь», или «сейчас» и «там» - уже не право; запретное сегодня - позволено завтра, и, может быть, именно в обязанность через месяц; организованный интерес становится силою и провозглашает «справедливым» то, что завтра будет ниспровергнуто «случайным» стечение обстоятельств [3].

Механизм применения права имеет свою вполне определенную цель обеспечить своевременное, правильное применение права и такую реализацию норм, которая бы обеспечивала оптимальный вариант, то есть благоприятно влияла на общественные отношения.

Это означает:

- вынесение решений на основе конституционно-правового мировоззрения;

- соблюдение общеправового критерия определенности;

- $\quad$ достижение ясности и недвусмысленности толкования правовой нормы;

- $\quad$ соблюдение правового равенства;

- обеспечение целесообразности и обоснованности принятого решения, отраженного в правоприменительном акте; 
- $\quad$ урегулированность конкретных общественных отношений даже при отсутствии нормативного регулирования.

Вместе с тем, для эффективного воздействия механизма большое значение имеет регулятивная функция права, где следует особо выделить такие составляющие, как статика и динамика. И в том случае, если правоприменение им соответствует, методы его воздействие будут результативны. Это важно, поскольку общественные отношения всегда находятся в динамике, и с их изменением происходит обновление правовых норм. Следует учитывать, что изменение правовых норм не может быть произвольным, оно всегда должно основываться на правовых началах, воплощенных в принципах права, что означает соблюдение конституционного равноправия и законности.

Так, в аналитическом документе КС РФ по вынесенным решения за 2016-2018 годы говорится: «неоднозначная правоприменительная практика противоречит конституционному принципу равенства, предполагающему одинаковый подход к лицам, находящимся в равных или сходных условиях, и ослабляет гарантии государственной защиты прав, свобод и законных интересов граждан» [4].

Особое значение придается принципу законности, как имеющему всеобъемлющий характер, поскольку он обеспечивает реализацию норм права. Он содействует воплощению на практике правового регулирования других общих правовых принципов: социальной справедливости, гуманизма, равноправия. Критерии эффективности реализации права следует искать в самом его предназначении, в реализации тех целей, которым он служит.

В основе формирования принципов права выступают потребности человека и общественные отношения, складывающиеся в целях их удовлетворения. С прогрессом общества развиваются принципы права, их содержание, когда на передний план может выйти та составляющая, которой ранее не придавалось особое значение. Так произошло с принципом справедливости, когда современное человечество выдвинуло на передний план соблюдение достоинства человека, которое становится самостоятельным принципом.

В этом проявляется аксиологическое начало принципов права, когда меняются одни правовые ценности, и появляются другие, и они становятся признаваемыми всем обществом. В результате формируется правосознание в обществе, когда личностные представления о ценностях в праве совпадают с таковыми в правоприменительной практике. В таком случае право проявляет свою инструментальную ценность, реализуясь через общеправовые принципы.

Принципы права выступают мерилом соответствия законодательных установок, обеспечивают соответствие смысла нормативно - правовых предписаний.

Важно отметить, что правоприменительному процессу предшествует правоусмотрение, означающее познавательно-оценочную деятельность, включающую исследование имеющихся материалов. В наиболее общем понимании правоприменительное усмотрение определяется, как предусмотренная правом возможность правоприменительного органа в конкретном деле субъективно выбирать наиболее оптимальное правоприменительное решение [5]. Пределы судебного усмотрения определяют пространство для воплощения свободы судьи при осуществлении определенных процессуальных действий. Правотворчество и реализация права представляют собой области человеческой деятельности ярко выраженного оценочного характера.

Без результативной правоприменительной деятельности реализация нормативно-правовых актов является невозможной. Поэтому правоприменительную деятельность и правоприменительное усмотрение как ее основной элемент можно считать одной из основ поддержания законности и правопорядка.

Центральным в определении понятия правоприменительного усмотрения является философское понятие выбора, то есть наличия нескольких альтернатив для реализации свободы воли субъекта правоприменения. Совершенно верно отмечает 
Е.И. Волкова что по своему характеру судебное правоприменение это познавательнооценочная деятельность [6].

Общеправовые принципы сегодня - полноценное правовое средство, используемое для воздействия на общественные отношения.

В условиях формирования правового государства, учитывая особые регулятивных свойства общеправовых принципов, их роль выходит на новый виток развития, переходу от теоретических исследований к практическому результату.

Они являются критерием прогрессивных изменений в обществе, а вынесение правомерного, обоснованного и справедливого судебного решения по делу возможно только на основе общеправовых принципов.

$$
* * *
$$

1. Байтин М. И. Сущность права. Современное нормативное правопонимание на грани двух веков. М.: Издательский дом «Право и государство», 2005. - с.543.

2. Kaufmann A. Fuenfundvierzig Jahre erlebte Rechtsphilosophie. - Frankfurtt f a.M., 1972. - S.104.

3. Ильин И.А. О сущности правосознания. URL: http://www.koob.pro/ilyin_i_a/o_sushnosti_pravosoznaniya. (дата обращения 10.07.2019).

4. Конституционно-правовые аспекты совершенствования нормотворческой деятельности (на основе решений Конституционного Суда Российской Федерации 2016-2018 годов). URL: http://www.ksrf.ru/ru/Info/Maintenance/Informationks/Pages/AspektsKS_2018.aspx.(дата обращения 10.07.2019).

5. Никитин А.А. Законность и правоприменительное усмотрение // Вестник Саратовской государственной юридической академии. - Саратов, 2015. - С. 141.

6. Волкова Е.И. Судебная познавательно-оценочная деятельность как вид мыслительной деятельности // «Черные дыры» в Российском Законодательстве. Юридический журнал. - М. 2007. - № 5. - С.116 .

\section{Шевко Н.Н., Куленкова Е.В. \\ Криминалистические особенности расследования по делам о побоях}

Дальневосточный юридчческий институт МВД России

(Россия, Хабаровск)

doi: $10.18411 / \mathrm{j}-07-2019-46$

idsp: ljournal-07-2019-46

\section{Аннотация}

В данной статье рассматривается краткая характеристика преступлений о побоях, их особенности и основные мероприятия, проводимые на первоначальном этапе расследования дел о побоях, в зависимости от версий происшедшего события.

Ключевые слова: здоровье человека, побои, квалификации преступления, причинение физической боли, кратковременное расстройство здоровья, административная ответственность, хулиганские побуждения, общественная опасность, криминальное поведение, степень тяжести, потерпевший.

\section{Abstract}

This article discusses a brief description of the crimes of beatings, their features and the main activities carried out at the initial stage of the investigation of cases of beatings, depending on the versions of the event.

Keywords: human health, the beatings, the qualification of the crime, the infliction of physical pain, short-term health disorder, administrative responsibility, hooliganism, social danger, criminal behavior, the severity, the victim.

Высшей ценностью любого государства является человек. Его права и свободы признаются и гарантируются принципами международного права, а также Конституцией Российской Федерации. Достоинство личности охраняется государством, согласно, свобода и личная неприкосновенность защищена и каждый имеет право на охрану здоровья. Никто не должен подвергаться пыткам, насилию, другому жестокому или унижающему человеческое достоинство обращению или наказанию. Нарушение этих конституционных положений является преступлением 